\title{
Hemoglobin Subunit Gamma-1
}

National Cancer Institute

\section{Source}

National Cancer Institute. Hemoglobin Subunit Gamma-1. NCI Thesaurus. Code C84982.

Hemog lobin subunit gamma-1 (147 aa, $\sim 16 \mathrm{kDa}$ ) is encoded by the human HBG1 gene.

This protein plays a role in the transport of oxygen to tissues of the fetal body. 